\title{
Evaluation of Growth and Immunological Indices of Allfemale Caspian salmon Salmo trutta caspius Induced by Gamma Irradiation
}

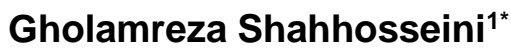 \\ https://orcid.org/0000-0002-3154-1809 \\ ${ }^{1}$ Nuclear Science and Technology Research Institute, Nuclear Agriculture Research School, Veterinary and animal \\ Science Department, Karaj, Alborz, Iran.
}

Editor-in-Chief: Alexandre Rasi Aoki

Associate Editor: Cheila Roberta Lehnen

Received: 2020.11.29; Accepted: 2021.08.16.

*Correspondence: gshahosseinil@yahoo.com; gshahhosseini@aeoi.org.ir Tel.: +98-26-34252322 (G.S.).

\section{HIGHLIGHTS}

- Gynogenesis didn't have significant effect on Caspian salmon immunological indices.

- Gynogenesis weren't have any effect on Caspian salmon blood chemical indices.

- Hematological indices didn't show any changes by Caspian salmon gynogenesis.

- Growth characteristics were improved by gynogenesis in Caspian salmon fish.

\begin{abstract}
Gynogenesis process via gamma irradiation) Caspian salmon (Salmo trutta caspius) with dosage of 450, 600, 750, 900 and 1050 Gy by gamma irradiation (Co60) with average weight of $2.31 \pm 0.22$ in a randomized design was transferred to 300 liters tanks $(n=3)$. For 6 months, growth indices including weight gain, feed conversion ratio, specific growth rate were examined. At the end of the period, 3 pieces from each experimental unit were caught and after anesthesia were used using clove oil (100 ppm) and blood sampling and sera isolation, immunological indices (lysozyme activity, complement activity and total immunoglobulin) were measured in fish of different groups. The results showed that the growth rate in the gynogen groups were higher than the control group $(p<0.05)$. The feed conversion ratio in the control treatment was significantly increased compared to experimental groups. The specific growth indices including of final weight $47.2 \%$, FCR $13.46 \%$ and SGR $10.9 \%$ were improved significantly in the experimental groups in comparison with the control group $(p<0.05)$. Immunological indices (lysozyme, complement activity and, immunoglobulin) in different groups weren't show significant changes ( $p>0.05)$. Therefore, the use of gynogenesis by using gamma irradiation concluded in Caspian Sea salmon, due to the lack of immunological indices and growth improvement.
\end{abstract}

Keywords: Caspian salmon (Salmo trutta caspius); gynogenesis; gamma irradiation; growth; innate immunity. 


\section{INTRODUCTION}

Caspian Salmon (Salmo trutta caspius) is one of the native species of the Caspian Sea [1]. This species is in extinction, associated with pollution increasing in Caspian Sea and watershed around it [2]. Due to high prices, It's considered as a suitable industrial species fisheries [3]. Male Early sexual maturity will be reduce growth efficiency in a salmon fish population [4]. Therefore, all-female population producing is a great importance in the species. Gynogenesis via Sperm irradiation and maternal genome inheritance is an Allfemale producing technique [5-9]. Gamma radiation results from nuclear decomposition reactions and have a basis effect on sperm genetic inactivation in gynogenesis process [16,17]. The technique divided to two kinds of meiotic and mitotic process. while in normal state, second polar body will comes out after fertilization, In meiotic process by using of early thermal, pressure or chemical shocks its exodus, will be prevented; and its genome content will use [10-12]. The radiation divided into two groups of high energy ionizing beams and low energy non-ionizing beams [13-15]. The fish farming environment is exposed to many primary and secondary pathogens. The immune system is very important to deal with these factors and before using any method, including chromosomal manipulations, it is very important to study its effect on the immune system $([18,19]$. Therefore, the aim of this study were the investigation of growth, biochemical and innate immunological indices of All- female Caspian salmon fish induced by gamma irradiation.

\section{MATERIAL AND METHODS}

At the first, three pieces of male and female mature Caspian salmon bloodstocks were prepared for semen and ovum collection. 7000 eggs and $50 \mathrm{~mL}$ semen (collected in plastic tube) were extracted by using a small pressure to the fish abdominal region, to the end of the body.

Sperm extracted from the male breeders mixed $(8.7 \times 109$ spermatozoa $/ \mathrm{ml})$. To ensure its quality (duration and type of sperm movement), an optimal microscope was used. Then, for genetic inactivation, its diluted with cohort solution ( $20 \mathrm{mM}$ Tris, $50 \mathrm{mM}$ glycine, $6 \% \mathrm{NaCl}, 2 \% \mathrm{kCl} \mathrm{pH}=9$ ) in a ratio of 1 to 4 [20] and then them Divided into $15 \mathrm{ml}$ containers. Then, they were irradiated at $5^{\circ} \mathrm{C}$ using Gamma cell PX-30-ISSIE, Russia using cobalt 60 at a speed of 0.137 Gy / s and with doses of 0, 450, 600, 750, 900 and $1050 \mathrm{~g}$ separately. In the next stage, fertilization was done by mixing the ovum and different irradiated spermatozoa, in separately groups $(n=3)$. Then, 10 minutes post-fertilization (mpf) during of 20 minutes thermal shock bath $\left(26 \pm 2^{\circ} \mathrm{C}\right)$ was used to eggs ploidy induction, [21,22]. Also, in control group $(n=3)$, normal ovum with irradiated spermatozoa was fertilized, without any thermal shock. To investigation of thermal shock (triploid group, $n=3$ ), normal ovum and spermatozoa along with thermal shock was used. Control group was fertilized by normal ovum and spermatozoa $(n=2)$. The different groups were transferred to 100 liter $(1 \mathrm{gram})$ tanks and then 30 grams fish were transferred to 300 liter tanks (20 repetitions per fish, $n=3$ ). All of the groups were fed ( $3 \%$ of body mass weight) by an artificial feed (Table 1$)$ twice per day.

Table 1. Analysis of feed chemical composition used in Caspian salmon feeding (percentage based on dry matter)

$\begin{array}{lc}\text { The chemical composition } & \% \\ \text { Dry matter } & 91 \\ \text { Crude protein } & 58 \\ \text { Crude lipid } & 15 \\ \text { Carbohydrate } & 6.6 \\ \text { Nitrogen-free extracts (NFE) } & 0.1 \\ \text { Ash } & 11.3\end{array}$

\section{Growth indicators}

At the end of the experiment the growth indicators containing of (Final weight, FCR and SGR) calculated in the groups at the following formula [23, 24]:

$(\mathrm{SGR}, \% /$ day $)=100 \times(\mathrm{LnW} 2-\mathrm{LnW} 1) / \mathrm{T}$

Feed conversion ratio $(\mathrm{FCR})=$ feed intake $(\mathrm{g}) /$ weight gain $(\mathrm{g})$

W1, W2 and T initial weight (g), final weight (g), number of days in the feeding period.

\section{Sampling and blood sampling}

At the end of breeding period, after 24 hours of starvation, three fishes from each experimental unit to biochemical parameters (red blood cell, white blood cell, hemoglobin, hematocrit, white blood cell count, 
$\mathrm{MCH}$ and MCV, TG, protein, cholesterol and albumin) and innate immune Indices (lysozyme complement activity, and immunoglobulin) were measured. For this purpose, fish were first anesthetized using clove oil (100 ppm) [25]. Blood sampling was performed using a heparin syringe of caudal vein. Then, for sera isolation, blood samples were centrifuged at $5000 \mathrm{rpm}$ for 10 minutes and then separated sera was kept at $80 \stackrel{\circ}{ } \mathrm{C}$ until the parameter's measurement. Sera biochemical and immunological parameters were measured by using Pars Azmoon Company's Test kits and by Auto-analyzer (ReflotronPlus, Roche, Mannheim, Germany).

\section{Statistical analysis}

The normality of data was evaluated using the colommograph-Smirnov test. Percentage data were converted to (Arc) sinus analysis before analysis. One-way analysis of variance (ONE-WAY-ANOVA) was used to compare the mean of data and the level of significance between the treatments by Tukey test at $5 \%$ probability level was done. Statistical analysis was performed by SPSS 17 software in Windows 10 environment and for drawing graphs Excel 2007 software in Windows 10 environment was used.

\section{RESULTS}

\section{Growing indicators}

The result showed that between the groups Control group had lowest Final weight and SGR $(p<0.05)$. Also the highest FCR was related to control group $(p<0.05)$. Between the gynogenic treatments didn't shown any differentiation along with growing indicators $(p>0.05)$ (Table 2).

Table 2. Comparison of growth performance (mean \pm SD) and survival rate in Caspian salmon fed by experimental diet during rearing period $(n=3)$.

\begin{tabular}{|c|c|c|c|c|c|c|c|}
\hline & Control & Triploid & 450 & 600 & 750 & 900 & 1050 \\
\hline $\begin{array}{l}\text { Initial weight } \\
\text { (g) }\end{array}$ & $1.02 \pm 0.12$ & $1.02 \pm 0.12$ & $1.02 \pm 0.12$ & $1.02 \pm 0.12$ & $1.02 \pm 0.12$ & $1.02 \pm 0.12$ & $1.02 \pm 0.12$ \\
\hline $\begin{array}{l}\text { Final weight } \\
\text { (g) }\end{array}$ & $110.6 \pm 0.12^{a}$ & $152.40 \pm 4.42^{\mathrm{b}}$ & $164.6 \pm 5.55^{b}$ & $163.6 \pm 3.99^{b}$ & $169.3 \pm 6.01^{b}$ & $165.2 \pm 5.45^{b}$ & $160.6 \pm 4.51^{b}$ \\
\hline $\begin{array}{c}\text { SGR ( } \% \text { day } \\
-1)\end{array}$ & $3.97 \pm 0.44^{b}$ & $3.56 \pm 0.28^{a}$ & $3.47 \pm 0.61^{\mathrm{a}}$ & $3.70 \pm 0.55^{\mathrm{ab}}$ & $3.54 \pm 0.41^{\mathrm{a}}$ & $3.54 \pm 0.22^{\mathrm{a}}$ & $3.42 \pm 0.32^{\mathrm{a}}$ \\
\hline FCR & $0.96 \pm 0.11^{a}$ & $1.03 \pm 0.51^{b}$ & $1.06 \pm 0.42^{b}$ & $1.08 \pm 0.44^{b}$ & $1.07 \pm 0.28^{b}$ & $1.05 \pm 0.31^{b}$ & $1.07 \pm 0.22^{b}$ \\
\hline
\end{tabular}

\section{Blood indices}

\section{Biochemical indices}

The results of this study showed that the total protein content in the triploid treatment was significantly lower than other treatments $(P<0.05)$ (Figure 1$)$, while this index wasn't showing any significant change among other treatments. Also, the results showed that biochemical parameters including of triglyceride, cholesterol, and albumin weren't showed significantly difference between the other groups (Figure 1). 

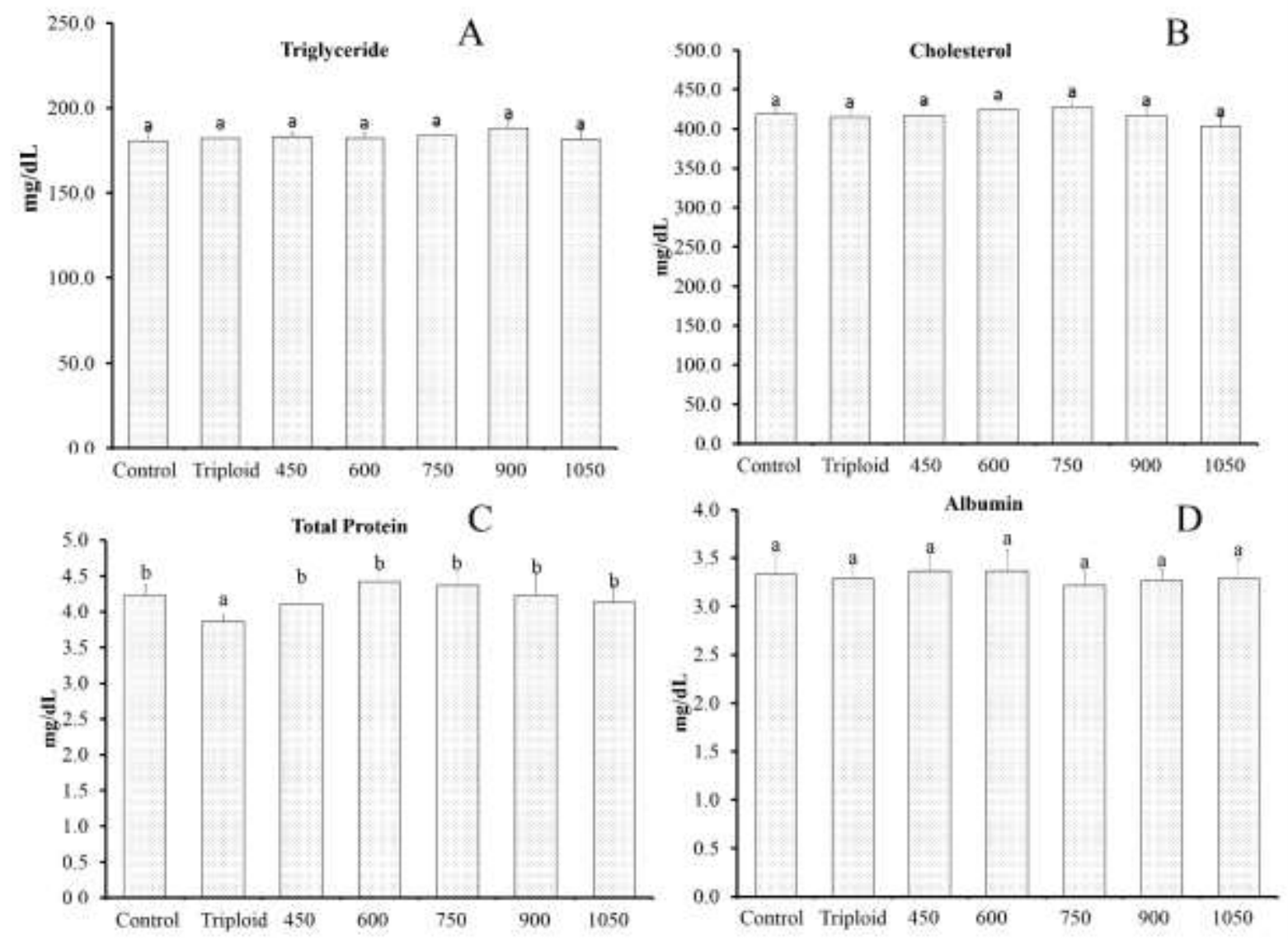

Figure 1. A) Triglyceride, B) cholesterol, C) total protein, and D) albumin in different treatments, lowercase letters represent a significant difference between the treatments.

\section{Hematological indices}

The results showed that white blood cells, red blood cells, hematocrit, and hemoglobin in the triploid group compared to the control group and the gynogenic treatments (450, 600, 750, 900, 1050 Gry) significantly decreased, while these indices had no relation between the treatments and the control group (Figure 2). MCV and MCH increased significantly in the triploid treatment compared to other treatments, and these indices did not show any significant difference in the treatments and control groups (Figure 2). 

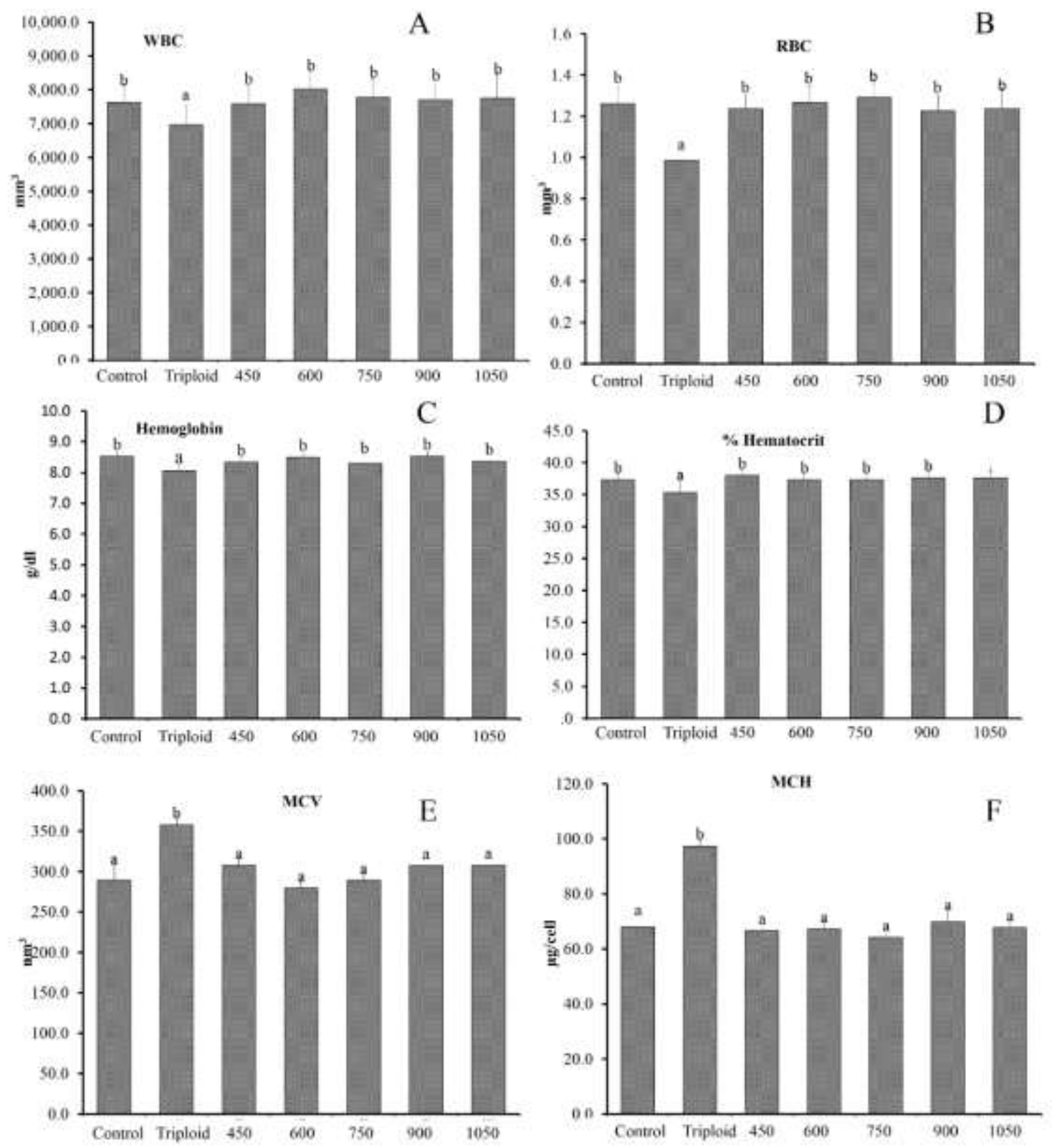

Figure 2. A) Red blood cell, B) white blood cell, C) Hemoglobin, D)\% hematocrit, E) MCV and F) MCH in different treatments, lowercase letters represent a significant difference between the treatments.

\section{White blood cell differential count}

The differential counting of white blood cells (monocyte, lymphocyte, and neutrophil) showed that there was no significant difference between the whole groups in terms of white blood cell type (Figure 3). 
A

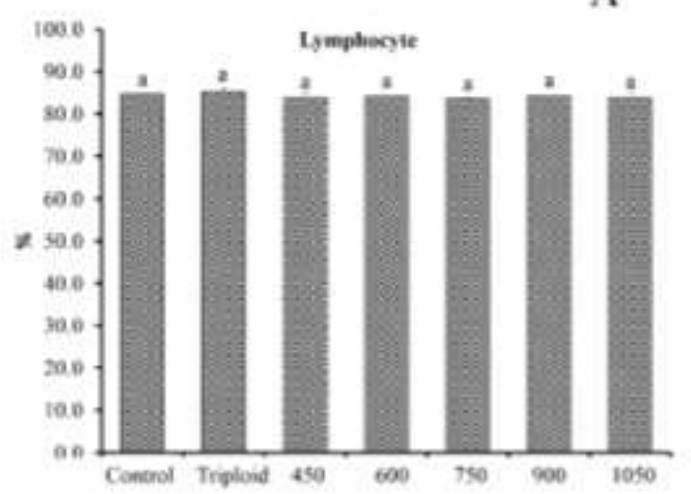

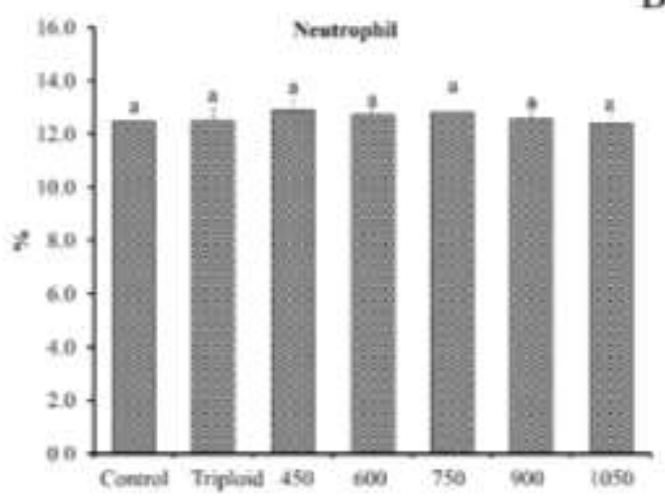

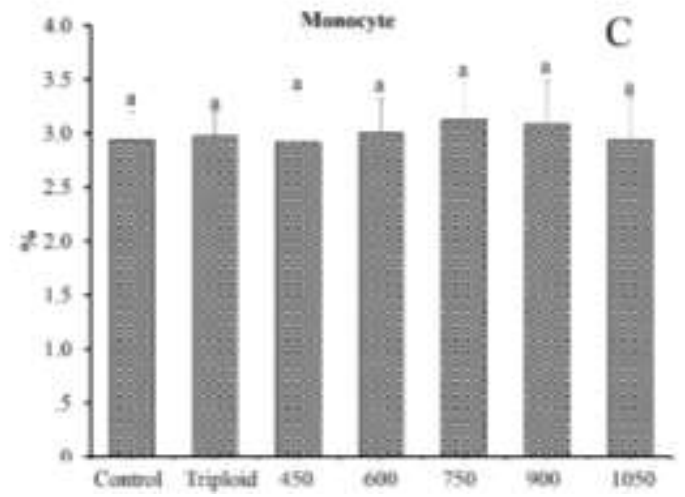

Figure 3. White blood cell differential count containing of A) Lymphocyte, B) neutrophil, and C) monocyte in different treatments, lowercase letters represent a significant difference between the treatments.

\section{Immunological Indicators}

Immunological indices (lysozyme, immunoglobulin, and complementarity activity) were show no significant difference between the treatments $(p>0.05)$. These indices in triploid treatment have decreased compared to other groups (Figure 4$)(p<0.05)$. The text continues here.
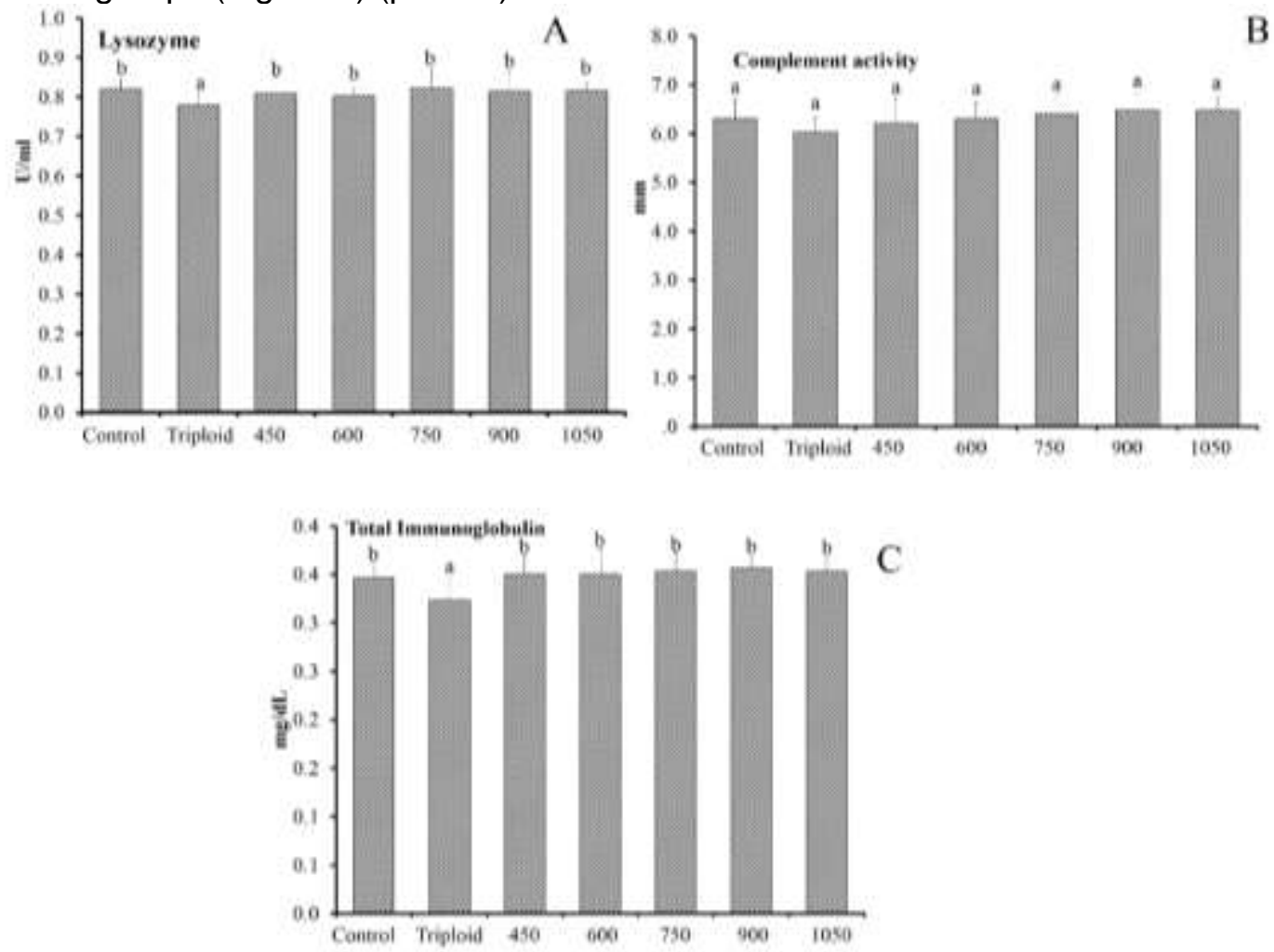

Figure 4. A) Lysozyme, B) complement activity and C) Total immunoglobulin in different treatments, lowercase letters represent a significant difference between the treatments. 


\section{DISCUSSION}

Meiosis Gynogenesis of salmon or successful crossbreeding with second polar globules and optimization of triploid function in this species depends on the time of onset of heat shock, which is basically about 10-15 minutes after fertilization in which triploid conditions can be created. By creating optimized conditions, meiotic gynogenesis can be produced [10-12]. Due to lower efficiency of mitotic gynogenesis [29,30]. In this study, the meiotic form was used to produce a population of all females. In previous studies, high yields of meiosis and heat shock were observed as a factor in ploidy manipulation in Atlantic salmon [29].

The results of this study indicate White and red blood cells, hematocrit, hemoglobin were decreased in the triploid treatment compared to the control and other treatments $(P<0.05)$. Meanwhile, these indices did not show any significant difference in other treatments compared to the control group. MCV and $\mathrm{MCH}$ indices increased significantly in the triploid treatment $(P<0.05)$. This increase could be due to an increase in the amount of hereditary material in the core cell of the triploid treatment, which, according to these results, does not require cytogenetic studies. Meanwhile, MCV and $\mathrm{MCH}$ indices did not show any significant difference between the control and the treated groups. The differential count of white blood cells including neutrophils, monocytes and lymphocytes did not show a significant difference among all groups. The physico-chemical conditions of the water and the number of bacteria present in the water indicate that the breeding conditions are optimal throughout the breeding period, which greatly reduces the mistakes caused by not considering the environmental factors of breeding. Sera immune parameters such as lysozyme, complementary activity and immunoglobulin significantly decreased in the triploid $(P>0.05)$, but these indices did not show any significant difference among other treatments considering that with any chromosomal manipulation, physiological parameters may change, and the lack of changes in biochemical and immunological indices indicates that fish produced by this method do not differ from normal fish and can withstand pathogens. Regarding the above results, we conclude that the substance is well done and the substrate treatment does not differ from the control treatment for hematologic and immunological status. This is due to the importance of these indices in aquaculture. Chromosomal manipulation in fish is done with the main purpose of increasing the product. However, this increase may be accompanied by changes in the characteristics of immunology, hematology, physiology and etc [26]. Due to the fact that fish have a more basic immune system than other vertebrates and on the other hand, the water environment is a suitable environment for transmitting pathogens. In the chromosomal manipulation of this group, vertebrates have two important safety indicators [27-30]. The results of this study showed that different doses used in the production of single-sex fish by gamma radiation on biochemical parameters (albumin, triglyceride and cholesterol), hematocrit (hematocrit, hemoglobin, red blood cell volume, $\mathrm{MCH}$ and $\mathrm{MCHC}$ ) and immunity (Total protein, complement activity, total globulin and lysozyme) has no negative effect on experimental treatments. Also, the results of this study indicate that in the triploid group, hematocrit, hemoglobin, red blood cell volume, $\mathrm{MCH}$ and $\mathrm{MCHC}$ indices were significantly different from other groups, which indicates that the thermal shock is appropriate and performed Successful triploid is in this group, which is consistent with other results [31-33]. One of the methods for increasing yield in a breeding season is the use of triploids [34]. But in this group of fish, the effects of this chromosomal change should be studied on immunological and hematological indicators [35]. In this research, the Caspian trout group was changed to other experimental biochemical parameters (albumin, triglyceride and cholesterol) and immunology (total protein, globulin and lysozyme), hematocrit, hemoglobin and red blood cells in this group, it has decreased compared to other groups. This can reduce the resistance to oxygen deficiency and the subsequent problems caused by environmental changes. The need for oxygen in fish, and in particular, in fishponds, is very important and due to the reduction in the carrying capacity of this group of fish, ultra-compact breeding methods cannot be used for breeding triploid fish, as compared to other ploidy groups of this group More problems are the lack of oxygen [27, 36-38]. The results of this study show that this method does not negatively affect chromosomal manipulation (induction of induction) on hematologic and immunological indices, so this method can be used to manipulate chromosomes without alteration in immunological and hematological indices. In recent years, a high level of aquatic disease has been introduced, such as VHS, IPN and IHN, along with imported eggs from other countries, which has led to much paralysis of this industry [39]. Therefore, it is necessary to use appropriate methods for self-sufficiency and production of eyed - egg, single-sex and native fish in the country. The results of this study indicate that the use of this method is applicable to the emergence of Caspian Sea salmon, while 900 doses were an appropriate dose for this method and this method did not affect the immunological and biochemical parameters of the sera. 


\section{CONCLUSION}

In recent years, a large number of aquatic diseases such as VHS, IPN and IHN have entered the country along with eggs imported from other countries, which has paralyzed a large part of the industry. Because fish have a more basic immune system than other vertebrates, and on the other hand, the aquatic environment as an aquatic habitat is a suitable environment for the transmission of pathogens. In chromosomal manipulations of this group of vertebrates, measuring safety indicators is doubly important. The results of the present study showed that different doses used in the production of single female fish using gamma rays on biochemical indicators (albumin, triglycerides and cholesterol), hematology (hematocrit, hemoglobin, erythrocyte volume, $\mathrm{MCH}$ and $\mathrm{MCHC}$ ) and immunological indices of different experimental treatments has no negative effect. According to the results, the use of this method for female's population producing of this species due to the high growth and on the other hand, due to the lack of change in blood and immunology characteristics, was concluded.

Acknowledgments: This study was supported by Nuclear Agriculture Research School, Nuclear Science and Technology Research Institute, AEOI, Karaj, Iran (CTS17:312).

\section{REFERENCES}

1. Kazanchev AN: Translated by: A. Shariati. Fishes of Caspian Sea and its watershed area. Iranian. Fish. Org. 1992;171.

2. Kiabi BH, Abdoli A, Naderi M: Status of fish fauna in the south Caspian basin of Iran East Zoology in the Middle. 1999;18:57-65.

3. Moghaddam JA, Abedian-Kenari A, b SK. Effects of dietary vegetal fatty acid and fat content on growth and acclimation to Caspian Sea water in Caspian brown trout (Salmo trutta caspius). 2013, 412-413:144-50.

4. Johnstone R, Simpson TH, Yungson AF, Whitehead C: Sex reversal rainbow trout. Aquaculture. 1979;18:13-9.

5. Refstie T, Stoss J, Donaldson EM: Production of all female coho salmon (Oncorhynchus kisutch) by diploid gynogenesis using irradiated sperm and cold shock. Aquaculture. 1982;29(1-2):67-82.

6. Quillet E, Gaignon J: Thermal induction of gynogenesis and triploidy in Atlantic salmon (Salmo salar) and their potential interest for aquaculture. Aquaculture. 1990;89(3-4):351-64.

7. Spruell P, Pilgrim K, Greene B, Habicht C, Knudsen K, Lindner K, Olsen J, Sage G, Seeb J, Allendorf F: Inheritance of nuclear DNA markers in gynogenetic haploid pink salmon. J. Hered. 1999;90(2):289-96.

8. Piferrer F, Benfey T, Donaldson E: Gonadal morphology of normal and sex-reversed triploid and gynogenetic diploid coho salmon (Oncorhynchus kisutch). J. Fish. Biol. 1994;45(4):541-53.

9. Wang H-P, Piferrer F, Chen S, Shen Z-g: Sex Control in Aquaculture: Wiley Online Library; 2018.

10. Chen R, Lou B, Xu D, Zhan W, Takeuchi Y, Yang F, et al. Induction of meiotic gynogenesis in yellow drum (Nibea albiflora, Sciaenidae) using heterologous sperm and evidence for female homogametic sex determination. Aquaculture. 2017;479:667-74.

11. Polonis M, Fujimoto T, Dobosz S, Zalewski T, Ocalewicz K: Genome incompatibility between rainbow trout (Oncorhynchus mykiss) and sea trout (Salmo trutta) and induction of the interspecies gynogenesis. J. Appl. Genet. 2018;59(1):91-7.

12. Pan ZJ, Zhu CK, Wang H, Chang GL, Ding HY, Qiang XG, Yu XS: Induction of meiotic gynogenesis in bagrid catfish (Pseudobagrus ussuriensis) with homologous sperm and its confirmation for female homogamety. Aquac. Res. 2017;48(11):5659-65.

13. Sharma A, Sharma R: Crop improvement and mutation breeding: Scientific Publishers; 2014.

14. Chourrout D: Gynogenesis caused by ultraviolet irradiation of salmonid sperm. J. Exp. Zool. 1982, 223(2):175-81.

15. Fairbrother JE: Viable gynogenetic diploid Mytilus edulis (L.) larvae produced by ultraviolet light irradiation and cytochalasin B shock. Aquaculture. 1994;126(1-2):25-34.

16. Yousefian M, Amirinia C, Bercsenyi M, Horvath L: Induced mitotic gynogenesis in common carp (Cyprinus carpio L.), optimizing irradiation dose of X-and gamma-ray. Animal breeding and feeding. 1997;46(2):97-105.

17. Dong Y-Q, Zhao W-X, Li X-H, Liu X-C, Gao N-N, Huang J-H, et al. Androgenesis, gynogenesis, and parthenogenesis haploids in cucurbit species. Plant cell reports. 2016;35(10):1991-2019.

18. Mou CY, Wang Y, Zhang QY, Gao FX, Li Z, Tong JF, et al. Differential interferon system gene expression profiles in susceptible and resistant gynogenetic clones of gibel carp challenged with herpesvirus CaHV. Dev. Comp. Immunol. 2018 (1), 52-64.

19. Shahhosseini, GR, Soltani M, Taheri Mirghaed A, and Zargar A: The effect of gynogenesis by use of gamma radiation on hematology and immunology indices in rainbow trout Oncorhynchus mykiss (Walbaum, 1792). 2016, 63-74.

20. Dorafshan S, Kalbassi MR: Effects of triploidy on the Caspian salmon Salmo trutta caspius haematology. Fish. Physiol. Biochem. 2008; 34:195-200. 
21. Soltani M, Mirzargar S: Effect of tricainemethanesulfonate (MS222), clove oil and electro-anaesthesia on respiratory burst activity in whole blood and serum alternative complement response in rainbow trout (Oncorhynchus mykiss), during the narcosis stage. Fish \& shellfish immunology. 2013;34(2):692-6.

22. Chourrout D: Gynogenesis caused by ultraviolet irradiation of salmonid sperm, J. Exp. Zool. 1982 (223), 175-81.

23. Wiegertjes GFSRJM, Van Muiswinkel.W. B Divergent selection for antibody production in common carp (Cyprinus carpio L.) using gynogenesis. Animal Genetics. 1994;25:251-7.

24. Gjedrem, T. ed., 2005. Selection and breeding programs in aquaculture (Vol. 2005, p. 360). Dordrecht, The Netherlands: Springer.

25. Misra CK, Das BK, Mukherjee SC, Pattnaik P: Effect of long term administration of dietary [beta]-glucan on immunity, growth and survival of Labeo rohita fingerlings. Aquaculture. 2006 (255), 82-94.

26. Li P, Burr GS, Goff J, Whiteman KW, Davis KB, Vega RR, et al. A preliminary study on the effects of dietary supplementation of brewers yeast and nucleotides, singularly or in combination, on juvenile red drum (Sciaenops ocellatus). Aquac. Res. 2005 (36), 1120-7.

27. Hashimoto K, Nakanishi T, Kurosawa Y: Isolation of carp genes encoding major histocompatibility complex antigens. Proceedings of the National Academy of Sciences. 1990;87(17):6863-7.

28. Hordvik I, Grimholt U, Fosse VM, Lie $\varnothing$, Endresen C: Cloning and sequence analysis of cDNAs encoding the MHC class II $\beta$ chain in Atlantic salmon (Salmo salar). Immunogenetics. 1993;37(6):437-41.

29. Marsden M, Freeman L, Cox D, Secombes C: Non-specific immune responses in families of Atlantic salmon, Salmo salar, exhibiting differential resistance to furunculosis. Aquaculture. 1996;146(1-2):1-16.

30. Koppang E, Lundin M, Press CM, Rønningen K, Lie $\varnothing$. Differing levels of Mhc class II $\beta$ chain expression in a range of tissues from vaccinated and non-vaccinated Atlantic salmon (Salmo salarL.). Fish. Shellfish. Immunol. 1998;8(3):183-96.

31. Sheehan RJ, Shasteen SP, Suresh AV, Kapuscinski AR, Seeb JE. Better growth in all-female diploid and triploid rainbow trout. Transactions of the American Fisheries Society. 1999;128(3):491-8.

32. Suresh A, Sheehan R: Muscle fibre growth dynamics in diploid and triploid rainbow trout. J. Fish. Biol. 1998;52(3):570-87.

33. Galbreath PF, Jean WS, Anderson V, Thorgaard GH: Freshwater performance of all-female diploid and triploid Atlantic salmon. Aquaculture. 1994;128(1-2):41-9.

34. Omoto N, Maebayashi M, Adachi S, Arai K, Yamauchi K: Sex ratio of triploids and gynogenetic diploids induced in the hybrid sturgeon, the bester (Huso huso female X Acipenser ruthenus male). Aquaculture. 2005;245:39-47.

35. Van Muiswinkel W, Lamers C, Rombout J: Structural and functional aspects of the spleen in bony fish. Res. Immunol. 1991;142(4):362-6.

36. Omoto N, Maebayashi M, Adachi S, Arai K, Yamauchi K: Sex ratios of triploids and gynogenetic diploids induced in the hybrid sturgeon, the bester (Huso huso femalex Acipenser ruthenus male). Aquaculture. 2005;245(1-4):3947.

37. Yamashita M, Jiang J, Onozato H, Nakanishi T, Nagahama Y: A Tripolar Spindle Formed at Meiosis I Assures the Retention of the Original Ploidy in the Gynogenetic Triploid Crucian Carp, Ginbuna Carassius auratus langsdorfii: (fish oocytes/gynogenesis/meiosis/spindle formation/histone H1 kinase). Development, growth \& differentiation. 1993;35(6):631-6.

38. Kalbassi M, Dorafshan S, Pourkazemi M, Amiri B: Triploidy induction in the Caspian salmon, Salmo trutta caspius, by heat shock. J. Appl. Ichthyol. 2009;25(1):104-7.

39. Fadaeifard F, Raissy M, Moumeni M, Faghani M: Evaluation of infectious hematopoietic necrosis, infectious pancreatic necrosis and viral hemorrhagic septicemia viruses in Iranian and imported rainbow trout eggs: across sectional study. J. Vet. Res. 2012;67(4):393-9.

40. Dadar M, Peyghan R, Rajabi-Memari H, Seifi Abad Shapouri M: Phylogenetic relationships of Iranian Infectious Pancreatic Necrosis Virus (IPNV) based on deduced amino acid sequences of genome segment $A$ and $B$ cDNA. Iranian. J. Fish. Sci. 2014;13(3):560-75.

(c) 2021 by the authors. Submitted for possible open access publication under the terms and conditions of the Creative Commons Attribution (CC BY NC) license (https://creativecommons.org/licenses/by-nc/4.0/). 